nhados por um grupo de bailarinas, intituladas "meninas do protocolo", que iam coreografando as diferentes teorias apresentadas. Houve ainda oportunidade, neste segundo acto, de fazer referência em apoteótico clima de festa, onde a entrega de prémios Nobel foi transportada para a nossa época (cem anos mais tarde) em jeito de entrega de Óscares de Hollywood, a alguns químicos galardoados com o Prémio Nobel da Química, nomeadamente, Fisher, Bequerel, Thomsom, Rutherford, Max Plank, Bhor e Marie Currie, pelo trabalho desenvolvido em áreas que contemplam temáticas integradas nos programas curriculares dos ensino básico e Secundário.

Tudo no espectáculo é inédito, desde as músicas e respectivas letras, até ao guião, que se foi transformando, à medida que havia necessidade de adequar os papéis às diferentes características e à evolução dos alunos.

Tanto o guião como as letras das músicas foram sendo construídos a partir de contribuições de diversos elementos do grupo de trabalho. O espectáculo tem um único suporte cénico que se vai transformando ao longo da acção. Começa por ser uma car- roça e logo se torna um barco, a seguir é um canhão, logo após é mesa de conferência e passerelle e as suas rodas são usadas pelos químicos na apresentação dos trabalhos durante a conferência celestial. Este elemento central do espectáculo foi concebido, de uma forma brilhante, pela cenógrafa e figurinista Olga Rego.

\section{O Grande Musical da Química foi} um sucesso e um excelente veículo de divulgação da Química, tendo-se mostrado gratificante para os dinamizadores e alunos/actores, uma vez que os objectivos propostos foram parcialmente atingidos, atendendo a que as datas disponibilizadas pelo Rivoli Teatro Municipal coincidiram com o final do ano lectivo e o início dos exames nacionais, o que impossibilitou a presença do público-alvo principal, alunos do $3^{\circ}$ Ciclo e Secundário. Foi sem dúvida uma oportunidade de crescimento dos alunos e motivação não só para a química como também em outras áreas.

O Grande Musical da Química representa ainda uma mais-valia para qualquer espectador, independentemente da sua idade.

\section{ConclusÃo}

Consideramos que este projecto tem qualidade para ser apresentado, noutras cidades, a outros alunos, mesmo para além do âmbito do Ano Internacional da Química, como meio fantástico de divulgação e motivação de e/ ou para o estudo da Química.

Está agendada uma nova representação no Teatro Constantino Nery em Matosinhos e ainda no Auditório de Gaia, em datas a anunciar.

Ainda no âmbito do Ano Internacional da Química, este mesmo grupo de professores está a preparar uma Tertúlia de Química, que incluirá um jantar, aberto a todos os interessados, professores, alunos, investigadores, etc., e que terá lugar no Café Guarany, situado na Avenida dos Aliados na cidade do Porto. Os interessados em participar poderão contactar a professora Lourdes Leitão - 917584775 ou mlourdesleitao@gmail.com.

\section{Lourdes Leitão, Conceição Mendonça, Fátima Sousa e Jorge Vieira (mlourdesleitao@gmail.com)}

Responsáveis pela concepção/dinamização do projecto "O Grande Musical da Química"

\title{
Falácia, de Carl Djerassi
}

\section{Q Ano Internacional da QUIIMICA 2011 \\ INVULGAR - que não é vulgar, co- mum; especial, raro, incomum (Dic. Houassis).}

... pois é. FALÁCIA não é um espectáculo qualquer mas, na realidade será um espectáculo INVULGAR!...

Invulgar porque não é uma coisa que se veja todos os dias. Invulgar porque talvez nunca mais volte a ter a possibilidade de ver.

Carl Djerassi, famoso químico e escritor norte-americano, assina o texto. Manuel João Monte, Professor Associado da Faculdade de Ciências da U.Porto (FCUP), fez a respectiva tradução para português. A companhia Seiva Trupe dá-Ihe corpo. É desta combinação que resulta "Falácia", título da peça que, no próximo dia 28 de Outubro, vai ser levada à cena no Teatro do Campo Alegre.

Inserida nas comemorações do Centenário da U.Porto e no programa preparado pelo Departamento de Química da Faculdade de Ciências da U.Porto para assinalar o Ano Internacional da Química, "Falácia" aborda temas transversais abrangendo a Arte, a Ciência (em particular a química) e a Ética.

Nesta peça - FALÁCIA - há um debate vivo, audacioso e cativante, com sentimentos amorosos a cruzarem-se e a prender o espectador pelo "bico". Num importante museu europeu, em Viena de Áustria, encontra-se a estátua de um rapaz nu, atribuída à era romana e que é a jóia da coroa do museu. Mas a ciência, através da química, desmistifica aquela era. E o valor artístico da obra, para além da data da sua feitura? - Aqui está um espectá- culo para quem se interessa por tudo que é importante na vida mas, muito especialmente, para quem se interessa por QUÍMICA e/ou MUSEOLOGIA.

Mas quem é Carl Djerassi? - Muito rapidamente: este génio, para além de ser autor de importantes obras teatrais, é um dos poucos cientistas norte-americanos que mereceram tanto a National Medal of Science (em 1973, pela primeira síntese de um anticoncepcional oral esteróide - a "pílula") e a National Medal of Technology. Entre as muitas dezenas de homenagens e títulos, recebeu o Prémio Wolf de Química, o primeiro prémio para a Aplicação Industrial da Ciência, conferido pela Academia Nacional de Ciências, e o mais importante prémio da American Chemical Society, a medalha Priestley.

Vanda Capitolino (quimica2011@spq.pt) www.spq.pt/quimica2011 